\title{
Fruit and vegetable consumption and mortality from all causes, cardiovascular disease, and cancer: systematic review and dose-response meta-analysis of prospective cohort studies
}

\author{
(c) (1) $(9)$ OPEN ACCESS
}

Xia Wang instructor in nutrition ${ }^{12}$, Yingying Ouyang research fellow ${ }^{2}$, Jun Liu research fellow ${ }^{2}$, Minmin Zhu instructor in biostatistics ${ }^{3}$, Gang Zhao instructor in medicine ${ }^{4}$, Wei Bao postdoctoral fellow $^{5}$, Frank B Hu professor ${ }^{6}$

${ }^{1}$ Department of Maternal and Child Health Care, School of Public Health, Shandong University, Jinan, China; ${ }^{2}$ Department of Nutrition and Food Hygiene, School of Public Health, Tongii Medical College, Huazhong University of Science and Technology, Wuhan, China; ${ }^{3}$ Department of Epidemiology and Biostatistics, School of Public Health, Tongji Medical College, Huazhong University of Science and Technology, Wuhan, China; ${ }^{4}$ Department of Cardiovascular Sciences, Shandong Provincial Hospital affiliated to Shandong University, Jinan, China; ${ }^{5}$ Epidemiology Branch, Division of Intramural Population Health Research, Eunice Kennedy Shriver National Institute of Child Health and Human Development, National Institutes of Health, Rockville, MD 20852, USA; ${ }^{6}$ Departments of Nutrition and Epidemiology, Harvard School of Public Health, Boston, MA 02115 , USA

\begin{abstract}
Objective To examine and quantify the potential dose-response relation between fruit and vegetable consumption and risk of all cause, cardiovascular, and cancer mortality.

Data sources Medline, Embase, and the Cochrane library searched up to 30 August 2013 without language restrictions. Reference lists of retrieved articles.

Study selection Prospective cohort studies that reported risk estimates for all cause, cardiovascular, and cancer mortality by levels of fruit and vegetable consumption.

Data synthesis Random effects models were used to calculate pooled hazard ratios and $95 \%$ confidence intervals and to incorporate variation between studies. The linear and non-linear dose-response relations were evaluated with data from categories of fruit and vegetable consumption in each study.

Results Sixteen prospective cohort studies were eligible in this meta-analysis. During follow-up periods ranging from 4.6 to 26 years there were 56423 deaths (11 512 from cardiovascular disease and 16 817 from cancer) among 833234 participants. Higher consumption of fruit and vegetables was significantly associated with a lower risk of all cause mortality. Pooled hazard ratios of all cause mortality were 0.95 (95\% confidence interval 0.92 to 0.98 ) for an increment of one serving
\end{abstract}

a day of fruit and vegetables ( $\mathrm{P}=0.001), 0.94$ (0.90 to 0.98 ) for fruit $(P=0.002)$, and 0.95 (0.92 to 0.99$)$ for vegetables $(P=0.006)$. There was a threshold around five servings of fruit and vegetables a day, after which the risk of all cause mortality did not reduce further. A significant inverse association was observed for cardiovascular mortality (hazard ratio for each additional serving a day of fruit and vegetables $0.96,95 \%$ confidence interval 0.92 to 0.99 ), while higher consumption of fruit and vegetables was not appreciably associated with risk of cancer mortality.

Conclusions This meta-analysis provides further evidence that a higher consumption of fruit and vegetables is associated with a lower risk of all cause mortality, particularly cardiovascular mortality.

\section{Introduction}

Increased consumption of fruit and vegetables has been recommended as a key component of a healthy diet for the prevention of chronic diseases. ${ }^{12}$ Cardiovascular disease and cancer are the two leading causes of death worldwide. ${ }^{3}$ Factors that can reduce the occurrence of these important diseases could contribute to important improvements in health and longevity. In recent years, there has been growing evidence that fruit and vegetable consumption is related to mortality, including mortality from cardiovascular disease and cancer ${ }^{4-6}$ The results, however, are not entirely consistent. While several studies found 
that consumption was associated with a lower risk of mortality, ${ }^{7-9}$ no significant differences in risk of mortality were observed between vegetarians and non-vegetarians in a British population..$^{10}$ In most studies, the association has been examined by categorising the main variable into fourths or fifths of daily consumption. ${ }^{11-13}$ There exists much uncertainty about the dose-response relation between consumption and the risk of mortality, especially for cancer, as recent large prospective studies have found no or minimal effects of consumption on overall cancer incidence or mortality. ${ }^{14-16}$

Understanding the relation between fruit and vegetable consumption and mortality is important for guiding consumer choices and prioritising dietary guidelines to reduce risk. We performed a meta-analysis of prospective cohort studies to quantify the dose-response relation between fruit and vegetable consumption and risk of all cause, cardiovascular, and cancer mortality.

\section{Methods}

\section{Search strategy}

We followed the Meta-analysis of Observational Studies in Epidemiology (MOOSE) $)^{17}$ for performing and reporting the present meta-analysis. We carried out a meta-analysis of prospective cohort studies that examined the associations of fruit and vegetable consumption with risk of all cause, cardiovascular, and cancer mortality. We systematically searched databases, including Medline (from 1950), Embase (from 1980), and the Cochrane Library (from 1960), between May 2013 and 30 August 2013 (last date searched). We used a search strategy that included truncated free text and exploded MeSH terms relevant to "fruits", "vegetables", "cardiovascular disease," "coronary disease," "myocardial ischemia," "stroke," "neoplasms," "cause of death," "mortality," "humans," "epidemiology," "follow-up studies," "prospective studies," and their variants. No restrictions were imposed on language of publications. We indentified additional articles by manually searching the reference lists from recent reviews and the extracted papers.

\section{Study selection}

We excluded letters, comments, reviews, meta-analyses, ecological studies, and animal studies. Studies were included if they were cohort studies, studied the effects of levels of fruit and vegetable consumption, and reported mortality from all causes, cardiovascular disease, or cancer as the outcomes of interest . To identify eligible studies, we used a two step selection process. Two independent investigators (GZ, JL) conducted an initial screening of all titles or abstracts and then evaluated all potentially relevant articles based on full text reviews. Studies were excluded if they did not meet all criteria.

\section{Data extraction and quality assessment}

Data extraction was conducted with a standardised data collection form. Two authors (GZ, JL) independently performed the extraction of data. We used hazard ratios as a measure of the association. The primary exposure variable was total fruit and vegetable consumption, but we also examined total fruit and total vegetables separately. Outcomes of interest in this study were all cause, cardiovascular, and cancer mortality. All outcomes were classified based on the World Health Organization's international classification of disease criteria. We recorded the following characteristics in the identified studies: first author, cohort name, country, publication year, age at entry, sex, sample size of the cohort, outcomes, duration of follow-up, method of assessment of fruit and vegetable consumption, ascertainment of outcomes, and variables that entered into the multivariable model as potential confounders. Regarding inclusion of studies and interpretation of data, a third investigator (YYO) was consulted to resolve discrepancies. Any disagreements were settled through consensus with all three authors. We assessed study quality with the Newcastle-Ottawa quality assessment scale. ${ }^{18}$ The system allowed a total score of up to 9 points ( 9 representing the highest quality). We derived a score that summarised eight aspects of each study.

\section{Statistical methods}

We used STATA version 12.0 (StataCorp LP, College Station, $\mathrm{TX)}$ to analyse the data. In this meta-analysis, we used hazard ratios and $95 \%$ confidence intervals as a measure of the effect size for all studies. The study by Strandhagen and colleagues did not report the relative risks or hazard ratios and confidence intervals in each consumption category, ${ }^{9}$ so we calculated the relative risks by using the total number of patients and the numbers of events. ${ }^{19}$ Another study by Colditz and colleagues reported only hazard ratios but not corresponding $95 \%$ confidence intervals. ${ }^{20} \mathrm{We}$ calculated $95 \%$ confidence intervals by using $\mathrm{P}$ values and effect estimates. ${ }^{21}$ All other studies included in the meta-analysis reported hazard ratios, estimated from Cox proportional hazards models, and corresponding $95 \%$ confidence intervals. We used the results of the original studies from multivariable models with the most complete adjustment for potential confounders. We used the inverse variance weighted method to obtain overall hazard ratios and $95 \%$ confidence intervals for an increase in consumption of one serving a day of fruit and vegetable. A random effects model accounted for variation between studies as this can provide more conservative results than a fixed effects model. ${ }^{22}$

The dose-response relation was estimated by using generalised least squares trend estimation, according to the methods developed by Greenland and Longnecker. ${ }^{23-25}$ We used the two stage generalised least squares trend estimation method, which first estimated study specific slope lines and then combined with studies in which the slopes were directly reported to obtain an overall average slope. ${ }^{25}$ Data on the amount of fruit and vegetable consumption, distributions of cases and person years, and hazard ratios and $95 \%$ confidence intervals were extracted to apply this method. We assigned the median consumption in each category of fruit and/or vegetable consumption to the corresponding hazard ratio for each study. If medians for that category were not reported, we estimated approximate medians by using the midpoint of the lower and upper bounds. If the highest category of the studies was open ended, we considered the difference from the lowest range to the median to be equivalent to the same difference in the closest adjacent category. If fruit and vegetable consumption was reported by servings or times, we converted it into the standard serving for the dose-response analysis, which was defined as $77 \mathrm{~g}$ for vegetables and $80 \mathrm{~g}$ for fruit. ${ }^{26}$

In addition, we examined non-linear associations between fruit and vegetable consumption and all cause mortality using a two stage random effects dose response meta-analysis. This was done by modelling consumption with the use of restricted cubic splines with three knots at fixed centiles $(10 \%, 50 \%$, and $90 \%)$ of the distribution. ${ }^{27}{ }^{28} \mathrm{We}$ first estimated a restricted cubic spline model with a generalised least squares regression, considering the correlation within each set of published hazard ratios. ${ }^{25} \mathrm{We}$ then combined the study specific estimates, using the restricted maximum likelihood method in a multivariate random effects 
meta-analysis. ${ }^{22}$ We estimated the pooled hazard ratios for servings of fruit and vegetables a day using a procedure to tabulate and plot results. ${ }^{29} \mathrm{~A}$ test for a non-linear relation was calculated by making the coefficient of the second spline equal to zero.

We evaluated heterogeneity between studies with Cochran's Q test $(\mathrm{P}<0.10)^{30}$ and used $\mathrm{I}^{2}$ to quantify the proportion of the total variation due to that heterogeneity. ${ }^{31}$ To explore the sources of heterogeneity among studies and test the robustness of the associations, we conducted subgroup analyses and several sensitivity analyses. We also examined the influence of individual studies on the overall risk estimate, which was investigated by recalculating the pooled estimates for the remainder of the studies by omitting one study at each turn.

Potential publication bias was assessed by the application of contour-enhanced funnel plots, ${ }^{32}$ Egger's linear regression test, ${ }^{33}$ and Begg's rank correlation test at the $\mathrm{P}<0.10$ level of significance. ${ }^{34}$ If publication bias was indicated, we further evaluated the number of missing studies in a meta-analysis by the application of the trim and fill method and recalculated the pooled risks estimate with the addition of those missing studies. ${ }^{35}$ Except where otherwise specified, a $\mathrm{P}$ value $<0.05$ was considered significant.

\section{Results}

\section{Literature search}

Figure $1 \Downarrow$ shows study selection process and results from the literature search. We identified 2019 articles from the Medline database, 3037 articles from the Embase database, and 2361 articles from the Cochrane Library. After exclusion of duplicates and papers that did not meet the inclusion criteria, we obtained 25 full articles of potentially relevant studies. After full text reviews, we excluded nine: one article with insufficient data for specific levels of fruit and vegetable consumption ${ }^{36}$; six articles that reported results of mixed diet, ${ }^{37-39}$ specific cancer mortality, ${ }^{40}$ or a marker of fruit and vegetable consumption ${ }^{5}$ or enrolled patients with diabetes ${ }^{41}$; and two further articles ${ }^{42}$ with data from the same cohort used in other studies. Sixteen articles with 56423 deaths (11 512 from cardiovascular disease and 16817 from cancer) reported from 833234 participants were included for the meta-analysis. ${ }^{7-9} 11-1320$ 43-51

\section{Characteristics of the included studies}

Tables $1 \Downarrow$ and $2 \Downarrow$ show the characteristics of the included studies, all of which had a prospective cohort design. The total number of participants (from 501 to 451 151) and deaths (from 42 to 25682 ) varied widely across cohorts. The duration of follow-up ranged from 4.6 years to 26 years. Four studies included only men, and 12 studies included men and women. Six studies were conducted in the United States, ${ }^{7820454651}$ four in Asian countries, ${ }^{11-1347}$ and six in Europe. ${ }^{94344} 48-50$ Three studies measured consumption of fruit and vegetables by diet records, ${ }^{45} 4851$ and all other studies used food frequency questionnaires.

All studies adjusted for age, except for one study of men born in 1913 because all the participants were at the same age. ${ }^{9}$ Most cohorts controlled for some conventional risk factors, including body mass index $(n=12)$, smoking $(n=13)$, and alcohol consumption $(n=12)$. Some cohorts also adjusted for physical activity $(n=8)$ and energy intake $(n=9)$, but few studies adjusted for other dietary variables or nutrients $(n=6) .^{11-13434548}$
Assessment of study quality yielded an average score of 7.1, and 10 studies had a score of 6.5 or above (see table A, appendix $1)$.

\section{Fruit and vegetable consumption and risk of all cause mortality}

Table $3 \Downarrow$ shows the results of the pooled analysis for all the included studies. The relation between fruit and vegetable consumption and risk of all cause mortality was evaluated in seven studies, ${ }^{7843-4648}$ comprising 553698 participants and 42 219 deaths. The pooled hazard ratio of all cause mortality was 0.95 (95\% confidence interval 0.92 to $0.98 ; \mathrm{P}=0.001$; fig $2 \Downarrow$ ) for an increment of one serving of fruit and vegetables a day, with significant heterogeneity $\left(\mathrm{P}<0.001, \mathrm{I}^{2}=82 \%\right)$.

Begg's rank correlation test indicated no publication bias $(\mathrm{P}=0.76)$, but Egger's linear regression test indicated possible publication bias for the association $(\mathrm{P}=0.006)$. We used the trim and fill method to recalculate our pooled risk estimate. The analysis suggested that the imputed risk estimate was $0.95(95 \%$ confidence interval 0.92 to 0.98 ), which is identical to our original risk estimate. No missing studies were imputed in the contour enhanced funnel plot (see fig A, appendix 2).

Using a restricted cubic splines model, we observed some evidence of a curvilinear association between total consumption of fruit and vegetables and risk of all cause mortality $(\mathrm{P}=0.01$ for non-linearity; fig $3 \Downarrow$ ). There was a dose-response relation between consumption of fruit and vegetables and decreasing risk of all cause mortality at consumption below five servings a day, but the risk did not decrease further with five or more servings a day. Compared with people who had no daily consumption of fruit and vegetables, the estimated hazard ratios of all cause mortality were 0.92 (95\% confidence interval 0.90 to 0.95$)$ for one serving/day of fruit and vegetables, 0.85 (0.81 to 0.90 ) for two servings/day, 0.79 ( 0.73 to 0.86$)$ for three servings/day, 0.76 (0.69 to 0.83 ) for four servings/day, 0.74 ( 0.66 to 0.82 ) for five servings/day, and 0.74 (0.65 to 0.82 ) for six or more servings/day.

Seven studies reported data for fruit or vegetable consumption and all cause mortality. ${ }^{911} 1343454951$ The summary estimates were 0.94 (95\% confidence interval 0.90 to $0.98 ; \mathrm{P}=0.002$; fig $4 \Downarrow)$ for each additional serving a day of fruit and 0.95 (0.92 to 0.99 ; $\mathrm{P}=0.006$; fig $5 \Downarrow)$ for vegetables. There was significant heterogeneity for both analyses $\left(\mathrm{P}<0.001, \mathrm{I}^{2}=77 \%\right.$ for fruit and $\mathrm{P}<0.001, \mathrm{I}^{2}=86 \%$ for vegetables).

For fruit consumption, we found no significant evidence of publication bias using Begg's rank correlation test $(\mathrm{P}=0.54)$, but Egger's linear regression test indicated possible publication bias $(\mathrm{P}=0.02)$. The application of the trim and fill method did not change the risk estimate (pooled hazard ratio 0.94, 95\% confidence interval 0.90 to 0.98 ). No missing studies were imputed in the contour enhanced funnel plots (see fig B, appendix 2). For vegetable consumption, no significant publication bias was detected (Begg test $\mathrm{P}=0.13$; Egger test $\mathrm{P}=0.36$ ).

We also found evidence of a non-linear association for fruit ( $\mathrm{P}=0.01$ for non-linearity; see fig $\mathrm{C}$, appendix 2 ) or vegetable consumption ( $\mathrm{P}=0.01$ for non-linearity; see fig $\mathrm{D}$, appendix 2 ) with risk of all cause mortality. A lower risk of all cause mortality was observed in association with higher fruit consumption at about two servings a day (hazard ratio 0.83 , 0.78 to 0.88$)$ and vegetable consumption at about three servings a day $(0.75,0.66$ to 0.86$)$. 


\section{Fruit and vegetable consumption and risk of cardiovascular mortality}

Total consumption of fruit and vegetables was investigated in four studies ${ }^{7843}$ with a total of 469551 participants and 6893 cardiovascular deaths. Fruit consumption was examined in six studies ${ }^{911-134351}$ with 677674 participants and 9744

cardiovascular deaths, and vegetable consumption was examined in six studies ${ }^{911-134351}$ with of 677674 participants and 9744 cardiovascular deaths.

The average reduction in the risk of cardiovascular disease mortality was $4 \%$ (hazard ratio $0.96,95 \%$ confidence interval 0.92 to $0.99 ; \mathrm{P}=0.02$ ) for each additional serving per day of fruit and vegetables combined (see fig E, appendix 2), 5\% (0.95, 0.91 to $1.00 ; \mathrm{P}=0.03$ ) for fruit consumption (see fig $\mathrm{F}$, appendix $2)$, and $4 \%(0.96,0.93$ to $0.99 ; \mathrm{P}=0.01)$ for vegetable consumption (see fig $\mathrm{G}$, appendix 2).

\section{Fruit and vegetable consumption and risk of cancer mortality}

Two studies reported data on the association between cancer mortality and total consumption of fruit and vegetables, ${ }^{843}$ seven studies on fruit, ${ }^{9} 13434749-51$ and eight studies on vegetables. ${ }^{9} 1320434749-51$ The hazard ratio for cancer mortality was 0.97 (95\% confidence interval 0.90 to $1.03 ; \mathrm{P}=0.31$; see fig $\mathrm{H}$, appendix 2) for each additional serving/day of total consumption, 0.99 ( 0.97 to $1.00 ; \mathrm{P}=0.06$; see fig I, appendix 2) for fruit, and 0.99 ( 0.97 to $1.01 ; \mathrm{P}=0.19$; see fig $\mathrm{J}$, appendix 2$)$ for vegetables.

\section{Subgroup and sensitivity analyses}

Table $4 \Downarrow$ shows the different subgroup analyses of studies on all cause mortality. The associations between fruit and vegetable consumption and risk of all cause mortality did not differ substantially by study location, sex, number of participants, duration of follow-up, or study quality.

To explore potential source of heterogeneity across studies, we carried out several sensitivity analyses (see table B, appendix 1). Heterogeneity between studies was mainly caused by one large study. ${ }^{43}$ For all cause mortality, after we excluded this study from the analysis there was no longer any evidence of significant heterogeneity for the combined consumption of fruit and vegetables $\left(\mathrm{I}^{2} 82 \%-0 \%\right)$, or for fruit consumption $\left(\mathrm{I}^{2}\right.$ $77 \%-0 \%)$. Exclusion of this study from the pooled estimate had little impact on the overall effect size.

To examine the impact of multivariable adjustment, we conducted additional sensitivity analyses by excluding studies that did not adjust for physical activity or energy intake. We also examined studies with some form of adjustment for socioeconomic status (such as education or income level). Overall, the sensitivity analyses did not lead to any change in the significance or direction of effect for the association between the combined consumption of fruit and vegetable and risk of all cause mortality (see table B, appendix 1).

To further confirm the robustness of the results, we conducted a series of sensitivity analyses by excluding one study that did not report hazard ratios. ${ }^{9}$ Exclusion of this study did not appreciably alter the results for total, cardiovascular, or cancer mortality (see table $\mathrm{C}$, appendix 1).

\section{Discussion}

This meta-analysis supports the theory that higher consumption of fruit and vegetables is associated with a reduced risk of mortality from all causes and cardiovascular disease. The risk of all cause mortality was decreased by $5 \%$ for each additional serving a day of fruit and vegetables, by $6 \%$ for fruit consumption, and by $5 \%$ for vegetable consumption. We observed a threshold at around five servings a day, after which there was no further reduction in risk. While we found a significant inverse association for cardiovascular mortality, higher consumption was not appreciably associated with risk of cancer mortality.

\section{Exploration of heterogeneity and publication bias}

In the meta-analysis of all cause mortality, one study with a large sample size contributed to most of the observed heterogeneity. ${ }^{43}$ Our results showed that about $82 \%$ of the variance in heterogeneity was due to the variation between studies. ${ }^{52}$ Sensitivity analyses showed that exclusion of this large study did not appreciably alter the pooled hazard ratios.

There were no missing studies imputed in regions of the contour enhanced funnel plots. Egger's linear regression test indicated that the $\mathrm{P}$ value was significant. No publication bias was found for Begg's rank correlation test. Also, the application of the trim and fill method did not change the average effect size, further suggesting that results were not affected by publication bias.

\section{Results in relation to other studies}

Adherence to a Mediterranean diet, with a relatively large amount of fruit and vegetables, has been shown to significantly decrease the risk of total mortality and mortality from cardiovascular diseases..$^{53}$ In older people from several European countries, lower mortality was related with greater adherence to a Mediterranean diet. ${ }^{38}$ Overall, about $10-30 \%$ lower risk of all cause mortality was found in most prospective studies comparing highest with lowest fruit and vegetable consumption. ${ }^{4-9} 1149$ A small study $(n=713)$ that used total serum concentrations of carotenoids as biomarkers of fruit and vegetable consumption further supported a risk reduction in mortality, with a hazard ratio of 0.50 for women in the highest third of serum concentration compared with the lowest third. ${ }^{5}$ The findings from our meta-analysis were consistent with a recent study showing that a lower consumption compared with five servings of fruit and vegetables a day was associated with higher mortality in a dose-response manner. ${ }^{44}$

For the reduction in total mortality, we found a threshold of around five servings a day of fruit and vegetables, after which the risk of death did not reduce further. Possible mechanisms might involve the availability of nutrients and the digestibility of fruit and vegetables, ${ }^{54}$ but further studies are needed to confirm our results.

Our study also showed that higher consumption of fruit and vegetables was associated with lower risk of mortality from cardiovascular disease but not cancer. The risk of cardiovascular mortality was decreased by $4 \%$ for each serving a day of the combined consumption of fruit and vegetables, by $5 \%$ for fruit, and by $4 \%$ for vegetables. In a previous meta-analysis of eight cohort studies, individuals who consumed more than five servings a day had a $26 \%$ lower risk of stroke than those who consumed less than three servings a day. ${ }^{26}$ In another meta-analysis of nine cohort studies on coronary heart disease, ${ }^{56}$ a $4 \%$ lower risk was reported for each additional serving a day of fruit and vegetables, with a standard serving calculated as $106 \mathrm{~g}$. As for the mechanisms for the inverse association between consumption of fruit and vegetables and cardiovascular mortality, antioxidant compounds and polyphenols in fruit and 
vegetables - such as vitamin $\mathrm{C}$, carotenoids, and flavonoids - have been shown to prevent the oxidation of cholesterol and other lipids in the arteries ${ }^{57}$ and to increase the formation of endothelial prostacyclin that inhibits platelet aggregation and reduces vascular tone. ${ }^{58}$ Results from large randomised controlled trials have shown that increased consumption of fruit and vegetables can contribute to a small decrease in blood pressure. ${ }^{59}$ Fruit and vegetables are good sources of magnesium and potassium, which have been inversely associated with mortality in previous studies. ${ }^{61-63}$ Plasma concentrations of antioxidants, such as alpha carotene and beta carotene, increase in parallel with increased consumption of fruit and vegetables, ${ }^{6064}$ and this could reduce the risk of cancer and cardiovascular disease. Some other components in fruit and vegetables such as vitamin $C$, carotenoids, and other phytochemicals also probably contribute to a reduced risk of mortality. ${ }^{4}$

The association between higher consumption of fruit and vegetables and risk of cancer has not been firmly established. Results from epidemiological studies are inconsistent, particularly for hormone dependent cancers such as breast and prostate cancer. ${ }^{65}$ Several studies showed no significant association between the consumption of either fruit or vegetables and total cancer risk, ${ }^{16}{ }^{66}$ whereas the Greek EPIC cohort study ${ }^{67}$ reported a significant reduction in total cancer risk associated with high consumption of both fruit and vegetables. In the EPIC study from 10 European countries, ${ }^{15}$ there was a weak inverse association between high consumption and total cancer risk. In our study, the pooled results indicate that higher consumption of fruit and vegetables was not appreciably associated with risk of cancer mortality, which suggests that increasing the amount of fruit and vegetables alone in an individual's diet might not provide an appreciable benefit on reducing cancer mortality. ${ }^{65}$ In addition to the recommendation of consuming adequate amounts of fruit and vegetables, the adverse effects of obesity, physical inactivity, smoking, and high alcohol intakes on cancer mortality should be further emphasised. It is possible, however, that fruit and vegetable consumption might have stronger effects on specific cancer sites. In addition, different types of fruit and vegetables might have different effects on cancer risk. Future studies are needed to be more specific about types of cancer and the role of different groups of fruit and vegetables.

\section{Strengths and limitations of the review}

This meta-analysis was based on several prospective cohort studies from various populations. The combined sample size was large and the follow-up period was long enough. The estimates from the fully adjusted models for each study were used in our analyses to reduce the potential of confounding. The dose-response analysis was conducted to evaluate the linear and non-linear relations. This can help to quantify the associations and test the shape of these possible associations. To examine the potential sources of heterogeneity and evaluate robustness in the subgroups, we performed several sensitivity analyses.

There were, however, several limitations of this meta-analysis. Because in most studies fruit and vegetable consumption was assessed by food frequency questionnaires, errors in measurement were inevitable. The imprecise measurement of consumption might have attenuated the true associations. In addition, few studies adjusted for other dietary factors, such as saturated fat intake and consumption of processed meat, etc. The inverse association between fruit and vegetable consumption and mortality could be related to a generally more healthy diet and lifestyle. Because all included studies were observational in nature, the results could be subject to residual or unmeasured confounding. Furthermore, there were differences in classifications of fruit and vegetables across studies. The types consumed differed according to geographical locations. These factors could affect our results. Our subgroup analyses, however, showed that the associations between consumption and risk of all cause mortality did not differ significantly by study location.

\section{Conclusions}

This meta-analysis provides further evidence that higher consumption of fruit and vegetables is associated with a lower risk of mortality from all causes, particularly from cardiovascular diseases. The results support current recommendations to increase consumption to promote health and overall longevity.

We thank Fuzhong Xue (director and professor of statistics, School of Public Health, Shandong University) for providing statistical advice.

Contributors: XW, GZ, YYO, and FBH contributed to conception and design. All authors were involved in analysis and interpretation of the data. MMZ, XW, and WB designed and conducted the statistical analysis. $X W, J L, W B$, and GZ drafted the manuscript, which was critically revised for important intellectual content by XW, WB, and FBH. All authors approved the final version. $\mathrm{FBH}$ is guarantor.

Funding: This work was funded by National Natural Science Foundation (NSFC 81071081) of China. WB was supported by the Intramural Research Program of the Eunice Kennedy Shriver National Institute of Child Health and Human Development, National Institutes of Health. The funders had no role in study design, data collection and analysis, preparation of the manuscript, or decision to publish.

Competing interests: All authors have completed the ICMJE uniform disclosure form at www.icmje.org/coi_disclosure.pdf (available on request from the corresponding author) and declare: no support from any organization for the submitted work; no financial relationships with any organizations that might have an interest in the submitted work in the previous three years; and no other relationships or activities that could appear to have influenced the submitted work.

Ethical approval: Not required.

Data sharing: No additional data available.

Transparency: The lead author (the manuscript's guarantor) affirms that this manuscript is an honest, accurate, and transparent account of the study being reported; that no important aspects of the study have been omitted; and that any discrepancies from the study as planned and registered have been explained.

1 Joint WHO/FAO Expert Consultation. Diet, nutrition and the prevention of chronic diseases. World Health Organ Tech Rep Ser 2003;916:1-149.

2 National Academy of Sciences CoDaH, National Research Council. Diet and health: implications for reducing chronic disease risk. National Academy Press, 1989.

3 World Health Organization. The top 10 causes of death. WHO,2012. www.who.int/ mediacentre/factsheets/fs310/en.

4 Agudo A, Cabrera L, Amiano P, Ardanaz E, Barricarte A, Berenguer T, et al. Fruit and vegetable intakes, dietary antioxidant nutrients, and total mortality in Spanish adults: findings from the Spanish cohort of the European Prospective Investigation into Cancer and Nutrition (EPIC-Spain). Am J Clin Nutr 2007;85:1634-42.

5 Nicklett EJ, Semba RD, Xue QL, Tian J, Sun K, Cappola AR, et al. Fruit and vegetable intake, physical activity, and mortality in older community dwelling women. J Am Geriatr Soc 2012;60:862-8

6 Trichopoulou A, Costacou T, Bamia C, Trichopoulos D. Adherence to a Mediterranean diet and survival in a Greek population. N Engl J Med 2003;348:2599-608.

7 Bazzano LA, He J, Ogden LG, Loria CM, Vupputuri S, Myers L, et al. Fruit and vegetable intake and risk of cardiovascular disease in US adults: the first National Health and Nutrition Examination Survey Epidemiologic Follow-up Study. Am J Clin Nutr 2002;76:93-9.

8 Genkinger JM, Platz EA, Hoffman SC, Comstock GW, Helzlsouer KJ. Fruit, vegetable, and antioxidant intake and all-cause, cancer, and cardiovascular disease mortality in a community-dwelling population in Washington County, Maryland. Am J Epidemiol 2004;160:1223-33.

9 Strandhagen E, Hansson PO, Bosaeus I, Isaksson B, Eriksson H. High fruit intake may reduce mortality among middle-aged and elderly men. The Study of Men Born in 1913. Eur J Clin Nutr 2000;54:337-41.

10 Key TJ, Appleby PN, Davey GK, Allen NE, Spencer EA, Travis RC. Mortality in British vegetarians: review and preliminary results from EPIC-Oxford. Am J Clin Nutr 2003;78:533S-8S. 


\section{What is already known on this topic}

The association between fruit and vegetable consumption and risk of mortality has been examined in many studies, but the dose dependency of this association has not been determined in a meta-analysis

\section{What this study adds}

Higher consumption of fruit and vegetables is associated with a reduced risk of all cause mortality, with an average reduction in risk of $5 \%$ for each additional serving a day ( $6 \%$ for fruit and $5 \%$ for vegetables)

There was a threshold around five servings a day, after which the risk of death did not reduce further

There was a significant inverse association for cardiovascular mortality, but higher consumption was not appreciably associated with cancer mortality

11 Nagura J, Iso H, Watanabe Y, Maruyama K, Date C, Toyoshima H, et al. Fruit, vegetable and bean intake and mortality from cardiovascular disease among Japanese men and women: the JACC Study. Br J Nutr 2009;102:285-92.

12 Nakamura K, Nagata C, Oba S, Takatsuka N, Shimizu H. Fruit and vegetable intake and mortality from cardiovascular disease are inversely associated in Japanese women but not in men. J Nutr 2008;138:1129-34.

13 Zhang X, Shu XO, Xiang YB, Yang G, Li H, Gao J, et al. Cruciferous vegetable consumption is associated with a reduced risk of total and cardiovascular disease mortality. Am J Clin Nutr 2011;94:240-6.

14 Willett WC. Fruits, vegetables, and cancer prevention: turmoil in the produce section. $J$ Natl Cancer 2010:102:510-1.

15 Boffetta P, Couto E, Wichmann J, Ferrari P, Trichopoulos D, Bueno-de-Mesquita HB, et al. Fruit and vegetable intake and overall cancer risk in the European Prospective Investigation into Cancer and Nutrition (EPIC). J Natl Cancer 2010;102:529-37.

16 George SM, Park Y, Leitzmann MF, Freedman ND, Dowling EC, Reedy J, et al. Fruit and vegetable intake and risk of cancer: a prospective cohort study. Am J Clin Nutr 2009:89:347-53.

17 Stroup DF, Berlin JA, Morton SC, Olkin I, Williamson GD, Rennie D, et al. Meta-analysis of observational studies in epidemiology. JAMA 2000;283:2008-12.

18 Wells G, Shea B, O'connell D, Peterson J, Welch V, Losos M, et al. The Newcastle-Ottawa Scale (NOS) for assessing the quality of nonrandomised studies in meta-analyses. 2000 www.ohri.ca/programs/clinical_epidemiology/oxford.htm.

19 McNutt L, Wu C, Xue X, Hafner JP. Estimating the relative risk in cohort studies and clinical trials of common outcomes. Am J Epidemiol 2003;157:940-3.

20 Colditz GA, Branch LG, Lipnick RJ, Willett W, Rosner B, Posner B, et al. Increased green and yellow vegetable intake and lowered cancer deaths in an elderly population. $A m \mathrm{~J}$ Clin Nutr 1985;41:32-6.

21 Gardner MJ, Altman DG. Confidence intervals rather than P values: estimation rather than hypothesis testing. BMJ 1986;292:746-50.

22 Jackson D, White IR, Thompson SG. Extending DerSimonian and Laird's methodology to perform multivariate random effects meta-analyses. Stat Med 2010;29:1282-97.

23 Berlin JA, Longnecker MP, Greenland S. Meta-analysis of epidemiologic dose-response data. Epidemiology 1993:218-28.

24 Greenland S, Longnecker MP. Methods for trend estimation from summarized dose-response data, with applications to meta-analysis. Am J Epidemiol 1992;135:1301-9.

25 Orsini N, Bellocco R, Greenland S. Generalized least squares for trend estimation of summarized dose-response data. Stata J 2006;6:40-57.

26 He FJ, Nowson CA, MacGregor GA. Fruit and vegetable consumption and stroke: meta-analysis of cohort studies. Lancet 2006;367:320-6.

27 Orsini N, Li R, Wolk A, Khudyakov P, Spiegelman D. Meta-analysis for linear and nonlinear dose-response relations: examples, an evaluation of approximations, and software. $\mathrm{Am}$ $J$ Epidemiol 2012:175:66-73.

28 Harre FE, Lee KL, Pollock BG. Regression models in clinical studies: determining relationships between predictors and response. J Natl Cancer 1988;80:1198-202.

29 Orsini N, Greenland S. A procedure to tabulate and plot results after flexible modeling of a quantitative covariate. Stata J 2011:11:1-29.

30 Hedges LV, Olkin I, Statistiker M. Statistical methods for meta-analysis. Academic Press, 1985.

31 Higgins JP, Thompson SG, Deeks JJ, Altman DG. Measuring inconsistency in meta-analyses. BMJ 2003;327:557-60.

32 Peters JL, Sutton AJ, Jones DR, Abrams KR, Rushton L. Contour-enhanced meta-analysis funnel plots help distinguish publication bias from other causes of asymmetry. $J$ Clin Epidemiol 2008;61:991-6.

33 Egger M, Smith GD, Schneider M, Minder C. Bias in meta-analysis detected by a simple, graphical test. BMJ 1997;315:629-34.

34 Begg CB, Mazumdar M. Operating characteristics of a rank correlation test for publication bias. Biometrics 1994;50:1088-101

35 Duval S, Tweedie R. Trim and fill: a simple funnel-plot-based method of testing and adjusting for publication bias in meta-analysis. Biometrics 2000;56:455-63.

36 Verlangieri A, Kapeghian J, El Dean S, Bush M. Fruit and vegetable consumption and cardiovascular mortality. Med Hypotheses 1985;16:7-15

37 Key TJ TM, Appleby PN, Burr ML. Dietary habits and mortality in 11000 vegetarians and health conscious people: results of a 17 year follow up. BMJ 1996;313:75-9.

38 Knoops KT, de Groot LC, Kromhout D, Perrin A, Moreiras-Varela O, Menotti A, et al. Mediterranean diet, lifestyle factors, and 10-year mortality in elderly European men and women. JAMA 2004:292:1433-9.

39 Kushi LH, Lew RA, Stare FJ, Ellison CR, el Lozy M, Bourke G, et al. Diet and 20-year mortality from coronary heart disease: the Ireland-Boston Diet-Heart Study. N Engl J Med $1985 ; 312: 811-8$

40 Jansen MC, Bueno-de-Mesquita HB, Räsänen L, Fidanza F, Nissinen AM, Menotti A, e al. Cohort analysis of fruit and vegetable consumption and lung cancer mortality in European men. Int J Cancer 2001;92:913-8.

41 Nöthlings U, Schulze MB, Weikert C, Boeing H, van der Schouw YT, Bamia C, et al. Intake of vegetables, legumes, and fruit, and risk for all-cause, cardiovascular, and cancer mortality in a European diabetic population. J Nutr 2008;138:775-81.

42 Crowe FL, Roddam AW, Key TJ, Appleby PN, Overvad K, Jakobsen MU, et al. Fruit and crome
Prospective Investigation into Cancer and Nutrition (EPIC)-Heart study. Eur Heart $J$ 2011;32:1235-43

43 Leenders M, Sluijs I, Ros MM, Boshuizen HC, Siersema PD, Ferrari P, et al. Fruit and vegetable consumption and mortality european prospective investigation into cancer and nutrition. Am J Epidemiol 2013:178:590-602.

44 Bellavia A, Larsson SC, Bottai M, Wolk A, Orsini N. Fruit and vegetable consumption and all-cause mortality: a dose-response analysis. Am J Clin Nutr 2013;98:454-9.

45 Tucker KL, Hallfrisch J, Qiao N, Muller D, Andres R, Fleg JL. The combination of high fruit and vegetable and low saturated fat intakes is more protective against mortality in aging men than is either alone: the Baltimore Longitudinal Study of Aging. $J$ Nutr 2005;135:556-61.

46 Steffen LM, Jacobs DR, Stevens J, Shahar E, Carithers T, Folsom AR. Associations of whole-grain, refined-grain, and fruit and vegetable consumption with risks of all-cause mortality and incident coronary artery disease and ischemic stroke: the Atherosclerosis Risk in Communities (ARIC) Study. Am J Clin Nutr 2003;78:383-90.

47 Sauvaget C, Nagano J, Hayashi M, Spencer E, Shimizu Y, Allen N. Vegetables and fruit intake and cancer mortality in the Hiroshima/Nagasaki Life Span Study. Br J Cancer 2003:88:689-94.

48 Rissanen TH, Voutilainen S, Virtanen JK, Venho B, Vanharanta M, Mursu J, et al. Low intake of fruits, berries and vegetables is associated with excess mortality in men: the Kuopio Ischaemic Heart Disease Risk Factor (KIHD) Study. J Nutr 2003;133:199-204.

49 Whiteman D, Muir J, Jones L, Murphy M, Key T. Dietary questions as determinants of mortality: the OXCHECK experience. Public Health Nutr 1999;2:477-87.

50 Hertog M, Bueno-de-Mesquita HB, Fehily AM, Sweetnam PM, Elwood PC, Kromhout D. Fruit and vegetable consumption and cancer mortality in the Caerphilly Study. Cancer Epidem Biomark 1996;5:673-7.

51 Sahyoun NR, Jacques PF, Russell RM. Carotenoids, Vitamins C and E, and mortality in an elderly population. Am J Epidemiol 1996;144:501-11.

52 Coory MD. Comment on: heterogeneity in meta-analysis should be expected and appropriately quantified. Int J Epidemiol 2010;39:932.

53 Sofi F, Cesari F, Abbate R, Gensini GF, Casini A. Adherence to Mediterranean diet and health status: meta-analysis. BMJ 2008;337:a1344.

54 Holst B, Williamson G. Nutrients and phytochemicals: from bioavailability to bioefficacy beyond antioxidants. Curr Opin Biotech 2008;19:73-82.

55 Otten JJ, Hellwig JP, Meyers LD. DRI, dietary reference intakes: the essential guide to nutrient requirements. National Academies Press, 2006

56 Dauchet L, Amouyel P, Hercberg S, Dallongeville J. Fruit and vegetable consumption and risk of coronary heart disease: a meta-analysis of cohort studies. $J$ Nutr 2006;136:2588-93

57 Asplund K. Antioxidant vitamins in the prevention of cardiovascular disease: a systematic review. J Intern Med 2002;251:372-92.

58 Lefer A. Prostacyclin, high density lipoproteins, and myocardial ischemia. Circulation 1990;81:2013-5

59 Appel LJ, Moore TJ, Obarzanek E, Vollmer WM, Svetkey LP, Sacks FM, et al. A clinical trial of the effects of dietary patterns on blood pressure. N Engl J Med 1997;336:1117-24.

60 John J, Ziebland S, Yudkin P, Roe L, Neil H. Effects of fruit and vegetable consumption on plasma antioxidant concentrations and blood pressure: a randomised controlled trial. Lancet 2002;359:1969-74.

61 Kaluza J, Orsini N, Levitan EB, Brzozowska A, Roszkowski W, Wolk A. Dietary calcium and magnesium intake and mortality: a prospective study of men. Am J Epidemiol 2010;171:801-7.

62 Zhang W, Iso H, Ohira T, Date C, Tamakoshi A. Associations of dietary magnesium intake with mortality from cardiovascular disease: the JACC study. Atherosclerosis 2012;221:587-95.

63 Yang Q, Liu T, Kuklina EV, Flanders WD, Hong Y, Gillespie C, et al. Sodium and potassium intake and mortality among US adults: prospective data from the Third National Health and Nutrition Examination Survey. Arch Intern Med 2011;171:1183-91

64 Zino S, Skeaff M, Williams S, Mann J. Randomised controlled trial of effect of fruit and vegetable consumption on plasma concentrations of lipids and antioxidants. $B M J$ 1997;314:1787-91

65 Key T. Fruit and vegetables and cancer risk. Br J Cancer 2010;104:6-11

66 Hung H, Joshipura KJ, Jiang R, Hu FB, Hunter D, Smith-Warner SA, et al. Fruit and vegetable intake and risk of major chronic disease. J Nat/ Cancer 2004;96:1577-84.

67 Benetou V, Orfanos P, Lagiou P, Trichopoulos D, Boffetta P, Trichopoulou A. Vegetables and fruits in relation to cancer risk: evidence from the Greek EPIC cohort study. Cancer Epidem Biomark 2008;17:387-92.

Accepted: 23 June 2014

\section{Cite this as: BMJ 2014;349:g4490}

This is an Open Access article distributed in accordance with the Creative Commons Attribution Non Commercial (CC BY-NC 3.0) license, which permits others to distribute, remix, adapt, build upon this work non-commercially, and license their derivative works on different terms, provided the original work is properly cited and the use is non-commercial. See: http://creativecommons.org/licenses/by-nc/3.0/. 


\section{Tables}

\begin{tabular}{|c|c|c|c|c|c|c|c|}
\hline First author & $\begin{array}{l}\text { Publication } \\
\text { year }\end{array}$ & Country & Study name & $\begin{array}{c}\text { No of } \\
\text { participants }\end{array}$ & $\begin{array}{c}\text { Age at } \\
\text { baseline } \\
\text { (years) }\end{array}$ & $\begin{array}{l}\text { Years of follow-up } \\
\text { (person years) }\end{array}$ & $\begin{array}{l}\text { Mortality endpoints (No of } \\
\text { cases) }\end{array}$ \\
\hline Bellavia $^{44}$ & 2013 & Sweden & $\begin{array}{l}\text { Swedish Mammography } \\
\text { Cohort and Swedish Men } \\
\text { Cohort }\end{array}$ & $71706^{*}$ & $45-83$ & $13(932$ 178†) & All cause $(11439)$ \\
\hline Leenders $^{43}$ & 2013 & $\begin{array}{l}10 \text { European } \\
\text { countries }\end{array}$ & EPIC & $451151^{*}$ & $25-70$ & $13(5864963 \dagger)$ & $\begin{array}{l}\text { All cause (25 682), CVD } \\
\text { (5125), cancer (10 438) }\end{array}$ \\
\hline Zhang $^{13}$ (men) & 2011 & China & $\begin{array}{l}\text { Shanghai Men's Health } \\
\text { Study }\end{array}$ & 61500 & $40-74$ & $4.6(282900)$ & $\begin{array}{l}\text { All cause (1951), CVD (635), } \\
\text { cancer (853) }\end{array}$ \\
\hline Zhang $^{13}$ (women) & 2011 & China & $\begin{array}{l}\text { Shanghai Women's Health } \\
\text { Study }\end{array}$ & 74942 & $40-70$ & $10.2(764408)$ & $\begin{array}{l}\text { All cause (3442), CVD } \\
(1023), \text { cancer (1485) }\end{array}$ \\
\hline Nagura" ${ }^{11}$ & 2009 & Japan & Japan Collaborative Cohort & $59485^{*}$ & $40-79$ & $13(756054)$ & $\begin{array}{l}\text { All cause (7606), CVD } \\
\text { (2243) }\end{array}$ \\
\hline Nakamura $^{12}$ & 2008 & Japan & Takayama Study & $29079^{*}$ & $\geq 35$ & $7(201156)$ & CVD (384) \\
\hline Tucker $^{45}$ & 2005 & US & $\begin{array}{l}\text { Baltimore Longitudinal } \\
\text { Study of Aging }\end{array}$ & $501 \ddagger$ & $34-80$ & $18(9018)$ & All cause $(306)$ \\
\hline Genkinger & 2004 & US & Odyssey Cohort & $6151^{*}$ & $30-93$ & $12(14960)$ & $\begin{array}{l}\text { All cause (910), CVD (378), } \\
\text { cancer (307) }\end{array}$ \\
\hline Steffen ${ }^{46}$ & 2003 & US & $\begin{array}{l}\text { Atherosclerosis Risk in } \\
\text { Communities }\end{array}$ & $11940^{*}$ & $45-64$ & 11 (131340†) & All cause (867) \\
\hline Sauvaget $^{47}$ & 2003 & Japan & Life Span Study & $38540^{*}$ & $34-103$ & $18(693720 \dagger)$ & Cancer (3136) \\
\hline Bazzano & 2002 & US & NHANES I & $9608^{*}$ & $25-74$ & 19 (159 304) & $\begin{array}{l}\text { All cause (2530), CVD } \\
\text { (1145) }\end{array}$ \\
\hline Rissanen $^{48}$ & 2002 & Finland & $\begin{array}{l}\text { Kuopio Ischaemic Heart } \\
\text { Disease Risk Factor }\end{array}$ & $2641 \neq$ & $42-60$ & $12.8(33800)$ & All cause (485), CVD (245) \\
\hline Strandhagen $^{9}$ & 2000 & Sweden & Study of Men Born in 1913 & $792 \ddagger$ & $54-80$ & 26 (20 592) & $\begin{array}{l}\text { All cause (390), CVD (226), } \\
\text { cancer (121) }\end{array}$ \\
\hline Whiteman ${ }^{49}$ & 1999 & UK & $\begin{array}{l}\text { Oxford and Collaborators } \\
\text { Health Check }\end{array}$ & $11090^{*}$ & $35-64$ & $9(93464)$ & All cause (598), cancer (257) \\
\hline Hertog $^{50}$ & 1996 & UK & Caerphilly Study & $2112 \ddagger$ & $45-69$ & $13.8(6874)$ & Cancer (114) \\
\hline Sahyoun $^{51}$ & 1996 & US & $\begin{array}{l}\text { Community dwelling } \\
\text { volunteers }\end{array}$ & $725^{\star}$ & $60-101$ & $12(8700 \dagger)$ & $\begin{array}{l}\text { All cause (217), CVD (108), } \\
\text { cancer (64) }\end{array}$ \\
\hline Colditz $z^{20}$ & 1985 & US & $\begin{array}{l}\text { Cohort study of } \\
\text { Massachusetts residents } \\
\text { aged } \geq 66\end{array}$ & $1271^{*}$ & $\geq 66$ & $5(6355 \dagger)$ & Cancer (42) \\
\hline
\end{tabular}

$C V D=$ cardiovascular disease; $E P I C=E u r o p e a n$ Prospective Investigation into Cancer and Nutrition; NHANES I=first National Health and Nutrition Examination Survey.

\section{*Men and women.}

†Person time estimated by multiplying number of participants by average follow-up time.

$\ddagger$ Men. 
Table 2 Characteristics of prospective studies of fruit and vegetable consumption in relation to mortality: exposure and outcome assessment, exposure levels, and covariates

\begin{tabular}{|c|c|c|c|c|c|}
\hline Study & $\begin{array}{c}\text { Exposure assessment } \\
\text { method }\end{array}$ & $\begin{array}{c}\text { Measure of } \\
\text { associations }\end{array}$ & Outcome assessment & Categories of consumption & Covariates in fully adjusted model \\
\hline $\begin{array}{l}\text { Bellavia, } \\
201344\end{array}$ & FFQ. Self administered & $\mathrm{HR}$ & $\begin{array}{l}\text { Ascertained through linkage } \\
\text { to Swedish Register of Death } \\
\text { Causes at National Board of } \\
\text { Health and Welfare }\end{array}$ & $\begin{array}{l}\text { Fruit and vegetables } \\
\text { (servings/day): } 0,0.5,1,2,3,4 \text {, } \\
5,8\end{array}$ & $\begin{array}{l}\text { Age, sex, BMI, physical activity, smoking } \\
\text { alcohol, energy intake, educational leve }\end{array}$ \\
\hline $\begin{array}{l}\text { Leenders, } \\
2013^{43}\end{array}$ & $\begin{array}{l}\text { Country specific FFQ and } \\
7 \text { day record }\end{array}$ & $\mathrm{HR}$ & $\begin{array}{l}\text { Record linkage with cancer } \\
\text { registries, boards of health, } \\
\text { and death indices, or active } \\
\text { follow-up }\end{array}$ & $\begin{array}{l}\text { Fruit and vegetables (g/day): } \\
\text { 178.8, 316.8, 468.4, 725.4. Fruit } \\
\text { (g/day): 74.6, 159.9, 250.1, } \\
\text { 403.0. Vegetables (g/day): } 91.1 \text {, } \\
\text { 151.6, 215.6, 339.4 }\end{array}$ & $\begin{array}{l}\text { Age, sex, centre, BMI, smoking status, } \\
\text { smoking duration, time since stopped } \\
\text { smoking, number of cigarettes smoked } \\
\text { a day, alcohol consumption, physical } \\
\text { activity, education, processed meat } \\
\text { consumption, vegetables and fruit () }\end{array}$ \\
\hline $\begin{array}{l}\text { Zhang, } 2011^{13} \\
\text { (men) }\end{array}$ & $\begin{array}{l}\text { FFQ. Interviewer } \\
\text { administered }\end{array}$ & $\mathrm{HR}$ & $\begin{array}{l}\text { Biennial home visits, record } \\
\text { linkage to Shanghai Cancer } \\
\text { Registry and Shanghai Vital } \\
\text { Statistics Registry, and death } \\
\text { certificates }\end{array}$ & $\begin{array}{l}\text { Fruit (g/day): } 14,71,129,196 \\
\text { 308. Vegetables (g/day): 144, } \\
232,307,398,583\end{array}$ & $\begin{array}{l}\text { Age, BMI, education, occupation, family } \\
\text { income, smoking, alcohol, physical } \\
\text { activity, multivitamin supplement use, } \\
\text { intakes of total energy and saturated fat } \\
\text { history of coronary heart disease, stroke } \\
\text { hypertension, or diabetes }\end{array}$ \\
\hline
\end{tabular}

\begin{tabular}{lllll}
\hline $\begin{array}{l}\text { Zhang, } 2011^{13} \\
\text { (women) }\end{array}$ & FFQ. Interviewer & HR & $\begin{array}{l}\text { Biennial home visits, record } \\
\text { administered }\end{array}$ & Fruit (g/day): 62, 155, 238, 330, \\
& & $\begin{array}{l}\text { linkage to Shanghai Cancer } \\
\text { Registry and Shanghai Vital }\end{array}$ & 489. Vegetables (g/day): 124, 261, 345, 506
\end{tabular}

Registry and Shanghai Vital 196, 261, 345, 506

Statistics Registry, and death certificates

\begin{tabular}{|c|c|c|c|c|c|}
\hline $\begin{array}{l}\text { Nagura, } \\
2009^{11}\end{array}$ & $\begin{array}{l}\text { FFQ. Self administered, } \\
\text { but confirmed by } \\
\text { comparing two } \\
\text { questionnaires } \\
\text { administered } 1 \text { year apart }\end{array}$ & $\mathrm{HR}$ & Reviewing death certificates & $\begin{array}{l}\text { Fruit (servings/day): } 0.9,2.3 \text {, } \\
\text { 3.9, 5.9. Vegetables } \\
\text { (servings/day): } 1.2,2.3,3.4,5.2\end{array}$ & $\begin{array}{l}\text { Age, BMI, sex, smoking status, alcohol } \\
\text { intake, physical activity, hours of sleep, } \\
\text { education years, perceived mental } \\
\text { stress, cholesterol intake, SFA intake, } \\
\text { n-3 fatty acids intake, sodium intake and } \\
\text { histories of hypertension and diabetes, } \\
\text { vegetable and bean intake (for fruit)/fruit } \\
\text { and bean intake (for vegetable) }\end{array}$ \\
\hline
\end{tabular}

\begin{tabular}{|c|c|c|c|c|c|}
\hline $\begin{array}{l}\text { Nakamura, } \\
2008^{12}\end{array}$ & $\begin{array}{l}\text { FFQ. Interviewer } \\
\text { administered. Validity and } \\
\text { reproducibility of FFQ } \\
\text { demonstrated by } \\
\text { comparing it with other } \\
\text { dietary assessment } \\
\text { methods }\end{array}$ & HR & $\begin{array}{l}\text { Data from office of National } \\
\text { Vital Statistics }\end{array}$ & $\begin{array}{l}\text { Men: fruit (servings/day): } 0.3 \text {, } \\
0.7,1.3,2.6 ; \text { vegetables } \\
\text { (servings/day): } 2.2,3.4,4,7.1 \\
\text { Women: fruit (servings/day): } 0.4 \text {, } \\
0.9,1.5,2.7 ; \text { vegetables } \\
\text { (servings/day): } 2.5,3.6,4.8,7.4\end{array}$ & $\begin{array}{l}\text { Age, BMI, total energy, marital status, } \\
\text { years of education, smoking, alcohol, } \\
\text { physical activity, history of hypertension } \\
\text { or diabetes, menopausal status, dietary } \\
\text { confounders (total protein, saturated fat, } \\
\text { sodium intake) }\end{array}$ \\
\hline Tucker, $2005^{45}$ & $\begin{array}{l}7 \text { day diet record. Self } \\
\text { completed, but ambiguous } \\
\text { or incomplete records } \\
\text { clarified by telephone } \\
\text { interview }\end{array}$ & HR & $\begin{array}{l}\text { Cause of death determined } \\
\text { by consensus of three } \\
\text { physicians using death } \\
\text { certificates, hospital and } \\
\text { physician records, and } \\
\text { autopsy data }\end{array}$ & $\begin{array}{l}\text { Fruit and vegetables } \\
\text { (servings/day): } 0-5, \geq 5\end{array}$ & $\begin{array}{l}\text { Age, total energy intake, saturate fat, } \\
\text { BMI, smoking, alcohol, physical activity, } \\
\text { dietary supplement use, saturated fat } \\
\text { intake, and secular trend (year of first } \\
\text { visit before } v \text { after } 1980 \text { ) }\end{array}$ \\
\hline $\begin{array}{l}\text { Genkinger, } \\
2004^{8}\end{array}$ & FFQ. Self administered & HR & Death certificates & $\begin{array}{l}\text { Fruit and vegetables } \\
\text { (servings/day): } 0.87,1.61,2.31 \text {, } \\
3.21,4.89\end{array}$ & $\begin{array}{l}\text { Age, BMI, smoking status, cholesterol } \\
\text { concentration, energy intake }\end{array}$ \\
\hline Steffen, $2003^{46}$ & $\begin{array}{l}\text { FFQ. Interviewer } \\
\text { administered. One } \\
\text { repeated measurement } \\
\text { during follow-up }\end{array}$ & HR & $\begin{array}{l}\text { Events investigated and } \\
\text { validated by using hospital } \\
\text { records, and deaths } \\
\text { investigated and validated by } \\
\text { using physician records and } \\
\text { next-of-kin interview }\end{array}$ & $\begin{array}{l}\text { Fruit and vegetables } \\
\text { (servings/day): } 1.5,2.5,3.5,5.0 \text {, } \\
7.5\end{array}$ & $\begin{array}{l}\text { Age, BMI, race, sex, and time dependent } \\
\text { energy intake, education, smoking, } \\
\text { physical activity, alcohol, hormone } \\
\text { replacement in women, waist:hip ratio, } \\
\text { systolic blood pressure, and use of } \\
\text { antihypertensive drugs }\end{array}$ \\
\hline $\begin{array}{l}\text { Sauvaget, } \\
2003^{47}\end{array}$ & $\begin{array}{l}\text { FFQ. Self administered. } \\
\text { Questionnaire compared } \\
\text { with records of } 24 \text { hour } \\
\text { dietary survey }\end{array}$ & HR & $\begin{array}{l}\text { Nationwide family registration } \\
\text { system }\end{array}$ & $\begin{array}{l}\text { Fruit (servings/week): 0-1, 2-4, } \\
5-7 \text {; vegetables (servings/week): } \\
0-1,2-4,5-7\end{array}$ & $\begin{array}{l}\text { Age, BMI, sex, radiation dose, city, } \\
\text { smoking status, alcohol habits, education } \\
\text { level }\end{array}$ \\
\hline $\begin{array}{l}\text { Bazzano, } \\
2002^{7}\end{array}$ & $\begin{array}{l}\text { FFQ. Interviewer } \\
\text { administered }\end{array}$ & $\mathrm{HR}$ & $\begin{array}{l}\text { Death certificates and } \\
\text { hospital discharge diagnosis }\end{array}$ & $\begin{array}{l}\text { Fruit and vegetables } \\
\text { (times/day): }<1,1,2, \geq 3\end{array}$ & $\begin{array}{l}\text { Age, sex, race, total energy intake, } \\
\text { history of diabetes, physical activity, } \\
\text { education, alcohol consumption, } \\
\text { smoking, vitamin supplement use }\end{array}$ \\
\hline
\end{tabular}


(continued)

\begin{tabular}{|c|c|c|c|c|c|}
\hline Study & $\begin{array}{l}\text { Exposure assessment } \\
\text { method }\end{array}$ & $\begin{array}{l}\text { Measure of } \\
\text { associations }\end{array}$ & Outcome assessment & Categories of consumption & Covariates in fully adjusted model \\
\hline $\begin{array}{l}\text { Rissanen, } \\
2002^{48}\end{array}$ & $\begin{array}{l}4 \text { day food record. } \\
\text { Interviewer administered }\end{array}$ & $\mathrm{HR}$ & $\begin{array}{l}\text { Linkage to national death } \\
\text { registry using Finnish social } \\
\text { security number }\end{array}$ & $\begin{array}{l}\text { Fruit and vegetables (g/day): } \\
<133,133-214,215-293 \\
294-408,>408\end{array}$ & $\begin{array}{l}\text { Age, BMI, examination years, urinary } \\
\text { excretion of nicotine metabolites and } \\
\text { alcohol consumption, systolic and } \\
\text { diastolic blood pressure, diabetes, serum } \\
\text { LDL, HDL and triglycerides, maximal } \\
\text { oxygen uptake, dietary factors (energy } \\
\text { adjusted intakes of vitamin } C \text { and E, } \beta \\
\text { carotene, lycopene, folate and fibre) }\end{array}$ \\
\hline $\begin{array}{l}\text { Strandhagen, } \\
20009\end{array}$ & $\begin{array}{l}\text { FFQ. Interviewer } \\
\text { administered }\end{array}$ & $\begin{array}{l}\text { Total number } \\
\text { of patients } \\
\text { and numbers } \\
\text { of events } \\
\text { reported }\end{array}$ & $\begin{array}{l}\text { Death certificates and } \\
\text { autopsy records }\end{array}$ & $\begin{array}{l}\text { Fruit (times/week): 0-1, 2-3, 4-5, } \\
\text { 6-7; vegetables (times/week): } \\
0-1,2-3,4-5,6-7\end{array}$ & Same age for all participants \\
\hline $\begin{array}{l}\text { Whiteman, } \\
1999^{49}\end{array}$ & $\begin{array}{l}\text { Self completed simple food } \\
\text { frequency questions }\end{array}$ & HR & $\begin{array}{l}\text { Confirmed by the Office for } \\
\text { National Statistics }\end{array}$ & $\begin{array}{l}\text { Fruit (times/week): 0-1, 1-3, 4-7; } \\
\text { vegetables (times/week): 0-1, } \\
\text { 1-3, 4-7 }\end{array}$ & Age, sex, smoking \\
\hline Hertog, $1996^{50}$ & $\begin{array}{l}\text { FFQ. Self administered, } \\
\text { validated against weighed } \\
7 \text { day food record }\end{array}$ & $\mathrm{HR}$ & Death certificates & $\begin{array}{l}\text { Fruit (g/day): } 0-27,28-70, \\
71-118,>118 ; \text { vegetables } \\
\text { (times/week): } 0-79,80-112, \\
113-149,>149\end{array}$ & $\begin{array}{l}\text { Age, BMI, smoking, social class, alcohol, } \\
\text { energy intake, fat intake }\end{array}$ \\
\hline $\begin{array}{l}\text { Sahyoun, } \\
1996^{51}\end{array}$ & $\begin{array}{l}3 \text { day food record. Self } \\
\text { completed }\end{array}$ & $\mathrm{HR}$ & $\begin{array}{l}\text { Annual index of deaths and } \\
\text { death certificates }\end{array}$ & $\begin{array}{l}\text { Fruit (g/day): }<163.8,163.8-301 \text {, } \\
301-437.6,>437.6 ; \text { vegetables } \\
\text { (g/day): }<89.2,89.2-187, \\
187-274.8,>274.8\end{array}$ & $\begin{array}{l}\text { Age, sex, disease status, disabilities } \\
\text { affecting shopping }\end{array}$ \\
\hline $\begin{array}{l}\text { Colditz, } \\
198520\end{array}$ & $\begin{array}{l}\text { FFQ. Interviewer } \\
\text { administered }\end{array}$ & $\mathrm{HR}^{*}$ & $\begin{array}{l}\text { Confirmed by Massachusetts } \\
\text { vital statistics register }\end{array}$ & $\begin{array}{l}\text { Vegetables (servings/day): }<0.7 \\
0.7-1.0,1.1-1.5,1.6-2.1, \geq 2.2\end{array}$ & Age \\
\hline
\end{tabular}

$\mathrm{BMI}=$ body mass index; $\mathrm{FFQ=food} \mathrm{frequency} \mathrm{questionnaire;} \mathrm{HDL}=$ high density lipoprotein; $\mathrm{HR}=$ hazard ratio; $L D L=$ low density lipoprotein; SFA=saturated fatty acid. ${ }^{*}$ Confidence intervals not reported. 
Table 3| Meta-analysis of fruit and vegetable consumption and risk of all cause, cardiovascular, and cancer mortality

Comparison

No of studies Cases/participants Pooled HR $(95 \% \mathrm{Cl}), \mathrm{P}$ value Heterogeneity $\left(\mathrm{I}^{2}\right), \mathrm{P}$ value Begg's test, Egger's test

All cause mortality

\begin{tabular}{|c|c|c|c|c|c|}
\hline Fruit and vegetables combined & $7^{7843-4648}$ & 42 219/553 698 & 0.95 (0.92 to 0.98 ), 0.001 & $82,<0.001$ & $0.76,0.006$ \\
\hline Fruit & $7^{9111343454951}$ & $40192 / 660186$ & 0.94 (0.90 to 0.98 ), 0.002 & $77,<0.001$ & $0.54,0.02$ \\
\hline Vegetables & $7^{911} 1343454951$ & $40192 / 660186$ & 0.95 (0.92 to 0.99$), 0.006$ & $86,<0.001$ & $0.13,0.36$ \\
\hline \multicolumn{6}{|l|}{ Cardiovascular mortality } \\
\hline Fruit and vegetables combined & $4^{784348}$ & $6893 / 469551$ & 0.96 (0.92 to 0.99 ), 0.02 & $42,0.16$ & $0.73,0.08$ \\
\hline Fruit & $6^{911-134351}$ & $9744 / 677674$ & 0.95 (0.91 to 1.00$), 0.03$ & $71,0.004$ & $0.90,0.28$ \\
\hline Vegetables & $6^{911-134351}$ & $9744 / 677674$ & 0.96 (0.93 to 0.99$), 0.01$ & $63,0.02$ & $0.88,0.73$ \\
\hline \multicolumn{6}{|l|}{ Cancer mortality } \\
\hline Fruit and vegetables combined & $2^{843}$ & $10745 / 457302$ & 0.97 (0.90 to 1.03 ), 0.31 & $68,0.08$ & - \\
\hline Fruit & $7^{913434749-51}$ & $16468 / 640852$ & 0.99 (0.97 to 1.00$), 0.05$ & $14,0.33$ & $0.37,0.19$ \\
\hline Vegetables & $8^{91320434749-51}$ & $16510 / 642123$ & 0.99 (0.97 to 1.01$), 0.19$ & $37,0.13$ & $0.27,0.13$ \\
\hline
\end{tabular}

$\mathrm{HR}=$ hazard ratio.

*Per serving/day. 


\begin{tabular}{|c|c|c|c|c|c|c|c|c|c|c|c|c|}
\hline \multicolumn{13}{|c|}{ Table 4| Stratified analysis on associations of fruit and vegetable consumption and all cause mortality } \\
\hline & \multicolumn{4}{|c|}{ Combined } & \multicolumn{4}{|c|}{ Fruits } & \multicolumn{4}{|c|}{ Vegetables } \\
\hline & No & $\mathrm{HR}^{*}(95 \% \mathrm{Cl})$ & P valuet & $I^{2}(\%)$ & No & $\mathrm{HR}^{\star}(95 \% \mathrm{Cl})$ & $P$ value & $I^{2}(\%)$ & No & $\mathrm{HR}^{*}(95 \% \mathrm{Cl})$ & $P$ valuet & $I^{2}(\%)$ \\
\hline \multicolumn{13}{|l|}{ Location: } \\
\hline US & 4 & $0.95(0.92$ to 0.97$)$ & 0.25 & 27.4 & 2 & 0.94 (0.86 to 1.02$)$ & 0.80 & 0.0 & 2 & 0.85 (0.67 to 1.07$)$ & 0.03 & 79.6 \\
\hline Europe & 3 & 0.96 (0.91 to 1.00$)$ & 0.01 & 88.6 & 3 & 0.93 (0.84 to 1.02$)$ & 0.02 & 73.2 & 3 & 0.91 (0.82 to 1.01 ) & 0.01 & 83.3 \\
\hline Asia & - & - & - & - & 2 & $0.93(0.90$ to 0.96$)$ & 0.28 & 13.5 & 2 & $0.98(0.92$ to 1.05$)$ & 0.01 & 95.6 \\
\hline \multicolumn{13}{|l|}{ Sex: } \\
\hline Men and women & 5 & $0.96(0.93$ to 0.99$)$ & 0.01 & 86.5 & 5 & $0.94(0.90$ to 0.99$)$ & 0.01 & 82.3 & 5 & 0.95 (0.92 to 0.99$)$ & 0.01 & 90.6 \\
\hline Men & 2 & 0.94 (0.89 to 0.98$)$ & 0.53 & 0.0 & 2 & 0.91 (0.85 to 0.98$)$ & 0.65 & 0.0 & 2 & 0.95 (0.90 to 1.01$)$ & 0.75 & 0.0 \\
\hline \multicolumn{13}{|c|}{ Follow-up time (years): } \\
\hline$\geq 13$ & 4 & $0.97(0.94$ to 1.00$)$ & 0.01 & 82.0 & 4 & $0.94(0.88$ to 1.00$)$ & 0.01 & 80.0 & 4 & 0.98 (0.95 to 1.02$)$ & 0.01 & 79.1 \\
\hline$<13$ & 3 & 0.93 (0.91 to 0.96$)$ & 0.36 & 1.3 & 3 & 0.94 (0.91 to 0.97$)$ & 0.39 & 0.0 & 3 & $0.82(0.67$ to 1.00$)$ & 0.01 & 88.0 \\
\hline \multicolumn{13}{|c|}{ Study quality score: } \\
\hline$\geq 8$ & 5 & $0.96(0.93$ to 0.99$)$ & 0.01 & 82.4 & 2 & 0.95 (0.88 to 1.03$)$ & 0.01 & 90.5 & 2 & $0.98(0.95$ to 1.04$)$ & 0.01 & 92.7 \\
\hline$<8$ & 2 & 0.93 (0.89 to 0.96$)$ & 0.30 & 8.9 & 5 & 0.93 (0.91 to 0.96$)$ & 0.65 & 0.0 & 5 & 0.89 (0.83 to 0.96$)$ & 0.01 & 76.3 \\
\hline \multicolumn{13}{|l|}{ No of participants: } \\
\hline$\geq 10000$ & 3 & $0.96(0.91$ to 1.00$)$ & 0.01 & 89.2 & 4 & $0.94(0.89$ to 0.99$)$ & 0.01 & 86.6 & 4 & $0.96(0.93$ to 1.00$)$ & 0.01 & 91.3 \\
\hline$<10000$ & 4 & $0.94(0.91$ to 0.97$)$ & 0.20 & 36.1 & 3 & 0.92 (0.87 to 0.98$)$ & 0.80 & 0.0 & 3 & 0.90 (0.80 to 1.01$)$ & 0.04 & 69.0 \\
\hline $\begin{array}{l}\mathrm{HR}=\text { hazard ratio. } \\
{ }^{*} \text { Per serving/day. } \\
\dagger \mathrm{P} \text { for heterogenei }\end{array}$ & & & & & & & & & & & & \\
\hline
\end{tabular}




\section{Figures}

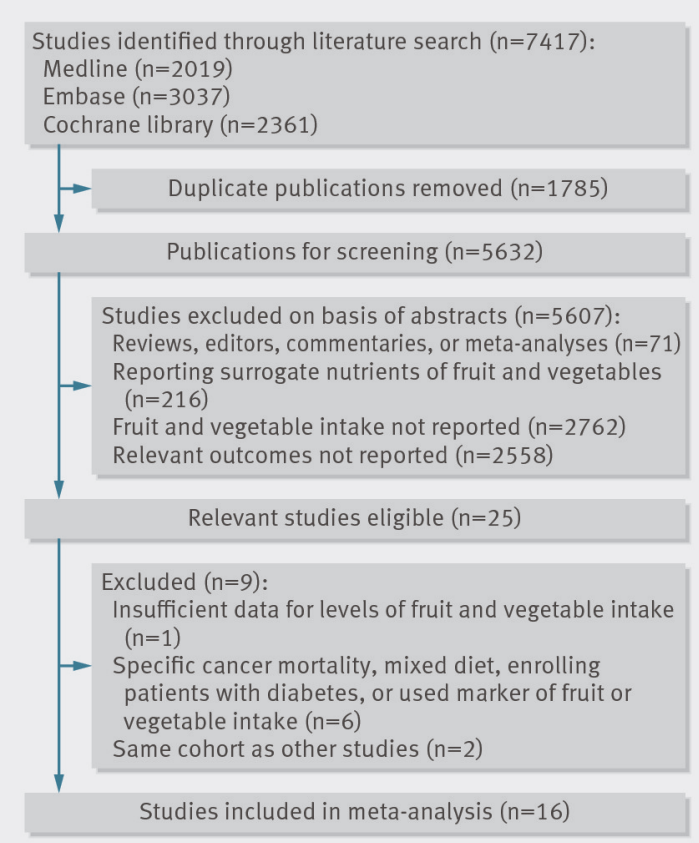

Fig 1 Selection of studies investigating effect of fruit and vegetable consumption on mortality

\begin{tabular}{|c|c|c|c|}
\hline Study & Hazard ratio $(95 \% \mathrm{Cl})$ & Weight & Hazard ratio $(95 \% \mathrm{Cl})$ \\
\hline Bellavia 2013 & $\rightarrow-$ & 17 & $0.94(0.92$ to 0.97$)$ \\
\hline Leenders 2013 & 두 & 20 & 0.99 (0.98 to 0.99$)$ \\
\hline Tucker 2005 & & 10 & $0.95(0.89$ to 1.01$)$ \\
\hline Genkinger 2004 & & 13 & 0.91 (0.86 to 0.95$)$ \\
\hline Steffen 2003 & & 15 & 0.95 (0.92 to 0.99$)$ \\
\hline Bazzano 2002 & & 15 & 0.97 (0.93 to 1.00$)$ \\
\hline Rissanen 2002 & t & 8 & $0.92(0.85$ to 0.99$)$ \\
\hline Overall: $P<0.001, I^{2}=82 \%$ & & 100 & 0.95 (0.92 to 0.98$)$ \\
\hline & 1 & & \\
\hline
\end{tabular}

Fig 2 Risk of all cause mortality associated with servings/day of fruit and vegetables. Weights are from random effects analysis

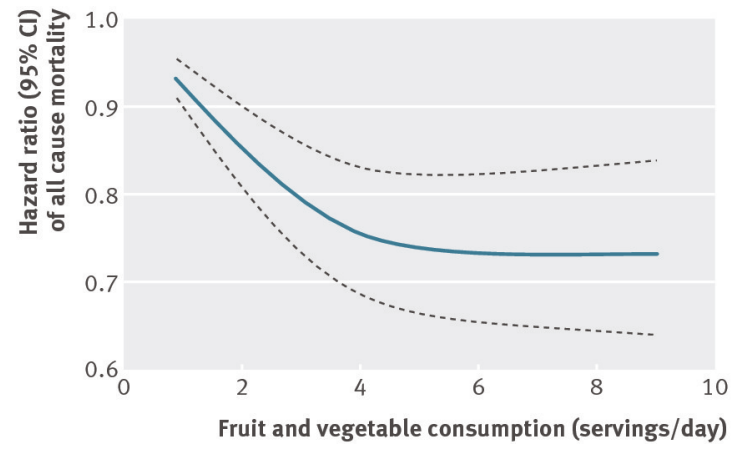

Fig 3 Dose-response relation between fruit and vegetable consumption and risk of all cause mortality 


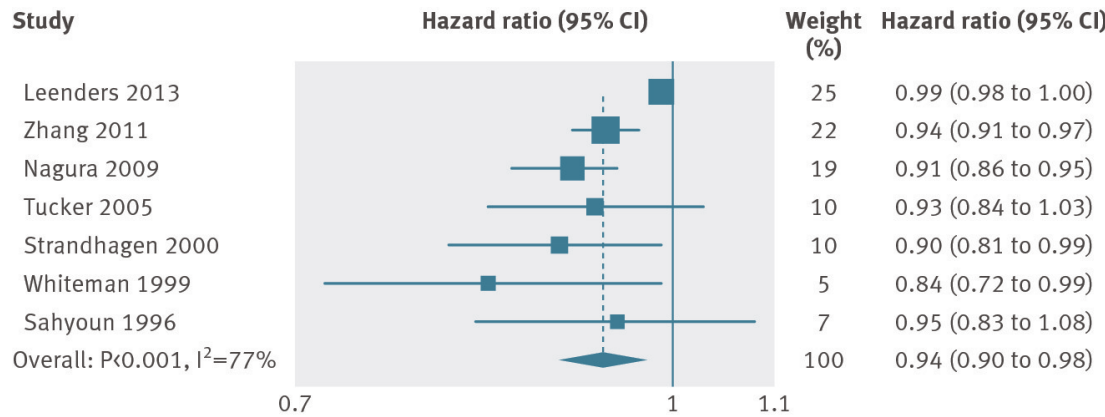

Fig 4 Risk of all cause mortality associated with servings/day of fruit. Weights are from random effects analysis

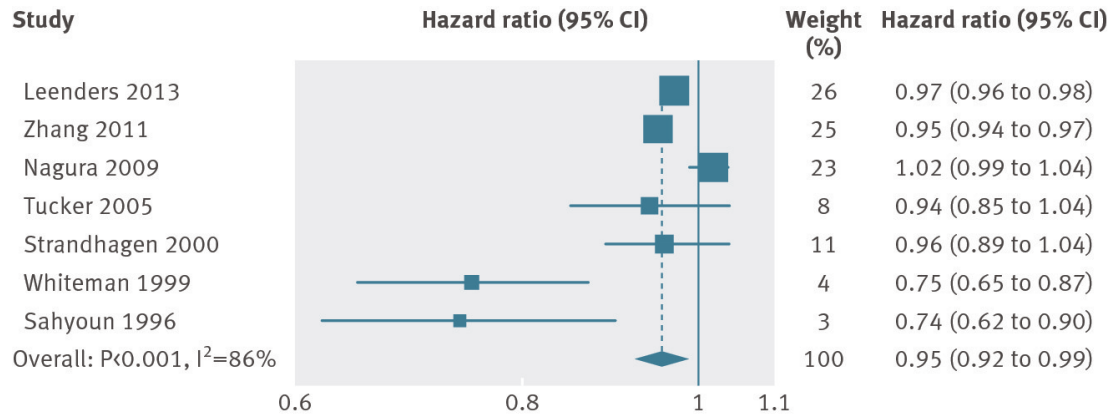

Fig 5 Risk of all cause mortality associated with servings/day of vegetables. Weights are from random effects analysis 